\title{
Effect of Blended Instructional Strategy on Commerce Students Academic Performance in Secondary Schools in Uyo Local Government Area of Akwa Ibom State-Nigeria
}

\author{
Etim, Paulinus J. ${ }^{1}$ \\ ${ }^{1} \mathrm{Ph}$. D, Ema, Iniobong Bassey \& Umoh, Nsidibe Charles, Dept. Of Educational Technology and Library Science, \\ University of Uyo, Nigeria \\ Correspondence: Etim, Paulinus J., Ph. D, Ema, Iniobong Bassey \& Umoh, Nsidibe Charles, Dept. Of Educational \\ Technology and Library Science, University of Uyo, Nigeria.
}

Received: December 16, 2016

Accepted: May 8, 2017 Available online: May 13, 2017

doi:10.11114/ijsss.v5i6.2419

URL: https://doi.org/10.11114/ijsss.v5i6.2419

\begin{abstract}
Teaching and learning are dynamic activities that are predicated on a number of factors. The pedagogical strategy used determines the effectiveness of the teacher and students' academic performance. This study was therefore on the effect of blended instructional strategy on Commerce students' academic performance in secondary schools in Uyo Local Government Area of Akwa Ibom State-Nigeria. Three research questions and three null hypotheses were raised to direct the study. The study adopted the pretest- postest non randomized quasi experimental design. Diffusion of Innovative theory and the Material-First-Rationale-Model were used to develop Commerce Instructional Package for experimentation. Two schools out of the 13 secondary schools in Uyo Local Government Area met the requirement for selection and were used for the study. The sample size of 240 students in both the urban and rural schools were selected and used for the study using the simple random sampling technique. An instructional package on Commerce was developed and used in treating the experimental groups while the control groups were taught using the expository teaching strategy. Both the control and the experimental groups were pretested before treatment. Commerce Performance Test was used to examine the effect of the package and the difference in students' performance. All the students in both control and the experimental groups were post-tested. Their scripts were marked and their scores used for analysis with the help of mean and Analysis of Co-variance. Results of the analysis showed a significant difference in academic performance of Commerce students taught with blended instructional strategy and those taught with expository method. There was also a significant difference in academic performance of male and female students as well as those students in urban and rural school location. Based on these results, the following recommendations were made to improve the teaching of Commerce and academic performance of students namely that blended instruction should be adopted in teaching Commerce and that in-service training, seminars and workshops should be organised by Government and other stake holders in Education to update the knowledge of teachers in the use of ICTs and web-based instructional strategies among other recommendations.
\end{abstract}

Keywords: blended instructional strategy, commerce instructional package, student's academic performance

\section{Introduction}

Teaching and learning in schools remain very important activities in education process. It implies the engagement and manipulation of the learners' sense organs for the purpose of transferring knowledge, skills, attitude, belief system etc. and training to acquire proficiency. For many decades now, researchers, scholar's educators, professionals' or other stakeholders in education have mounted researches to redefine the ways to teach and cause students to learn. Many theories and models have been postulated to guide the processes. Over these years emphasis was on setting the classrooms and individual learners to conform. The modes of information transfer of course are often verbal and learners remain passive. The audio visual movement came up with a synergy of engaging more sense organs to get teaching and learning more productive and rewarding. Presently, the learners own their learning processes.

The advent of Information and Communication Technologies (ICTs) has come to strengthen the Innovative skills of man in task performance and has gained momentum in the classroom. The versatile tool of computer has led to generation of many systems and techniques of teaching and learning causing an increasing quest in the improvement of 
students' information processing abilities. This can be regarded as enriched instruction or media supplemented learning. Information technology revolution has also led to rapid expansion across a wide range of areas in the modern world. This has made it an essential requirement for schools, Universities and other educational institutions to identify and improve teaching and learning environments as well as cope with an ever increasing demand for education and training. New internet bases education techniques have reduced traditional (face-face) place and time obstacles and have provided students access to information whenever and ho wever they want.

In the views of Scida and Saury (2006), Salamah (2005) Web-based education is a new education model which can be used to support the acquisition of the new information skills and for the enrichment of students learning habit and experiences. Diversified instructional processes are rapidly becoming more prevalence. However, online teaching-learning environment lack many advantages that face-to-face environment have, which led to the motion of blended learning. Rose and Gage (2016) and Etim (2016) reported that online education student tend to be less satisfied with totally online courses when compared to traditional courses. Therefore, a combination of online teaching and traditional learning environment could be much more useful in solving educational problems and meeting educational needs especially of the learners. Furthermore, Graham (2006) argues that blended Instructional strategy was de veloped for its potential advantages in offering a more effective education, convenience and access to learning environment.

Blended instructional strategy is referred to as hybrid and mixed teaching and it is used in very different ways by many researchers. Throne (2003) defines blended instruction as an education model which can integrate e-learning and can improve in parallel with the new technological development with traditional (face-to-face) teaching and provides integration in the classroom. Graham (2006) also looks at blended instructional approach as a combination of face-to-face teaching activities that are integrated in a planned, pedagogically valuable way and where some of the face-to-face classroom interaction is replaced by online activities. Blended instruction is an inno vative type of education carried out by combining the positive aspects of different learning approaches. Blended instruction provides a big convenience for the course to achieve its target by combining the face-to-face interaction in traditional teaching and providing accessibility to instruction in time and in space with embodied enrichment in materials provided by web-based teaching and or mediated instruction (Etim, 2016).

Male and female are noted for their respective performance at various areas of engagements. Angrist (2009) reports that girls have greater verbal ability than boys, boys have greater spatial abilities than girls. Boys perform well in mathematics and science related subjects while Guetzeekeep (2008) reported that women are higher in verbal ability than men and perform lower in sciences. Equally Mbaba (2010) established that gender is a cultural construct that distinguishes the roles, behaviour, mental and emotional characteristics between male and females developed by the society. Equally, Kim and Chang (2007) reported that computer use for school work had significant effect on achievement of overall students although the same effect was not significant for migrant students. The effect of computer use for their own learning was significantly lower for female students than male.

Okoeye (2009) studied the effect of gender, socio-economic status and school location on students' performance in integrated science. Results show that there is no significant interaction between gender and socio-economic status on student's achievement in integrated science. Mkpughe (2008) discovered that males learn better in science than their female counterparts. The school environment is a major determinant of scholastic performance because of the existence of a significant interplay between the learning process and the learning environment in which the child finds himself. A stimulating school environment arouses the students to learn especially in the area of science. Okeye (2009) and Owoeye and Yara (2007) reported a significant difference between students' academic performance of rural and urban secondary schools in school certificate examinations and that students in urban areas had better academic achievement than their rural counterparts. In the same vein, Okworo (2008) observed that students from urban areas tended to do better in chemistry than their rural counterparts and also submitted that academic performances of students are due to differential environmental stimulations.

The ultimate aim of teaching and learning is to enhance students' performance and achievement of expected and immediate results especially in knowledge and skill acquisition, development of acceptable norms, belief system, attitudes and interest etc. as well as passing internal and external examinations. To achieve this, the learners must be well taught with a combination of diversified and innovative pedagogical strategies. Unfortunately, the researchers observe an abysmal and dwindling level of performance of students in Commerce as an important course in Business management leading to economic emancipation through planning, office management and response to productive ventures and industrialization. One would observe a future that is bleak in overall economic development if this trend is allowed to continue at geometrical progression as it is.

The mode of teaching this subject in secondary schools in Uyo Local Government Area is still verbal and teachers centered with its adverse implications. Uyo is the capital of Akwa Ibom in Nigeria which of course should set the pace 
for other Local Government Areas to follow through their educational zones. Mediated instruction is not pronounced in most of the 13 secondary schools in the Local Government Area. The essence of this study therefore is to examine if the adoption of blended instructional strategy could change the situation and promote learning of commerce by students and develop students' interest in the subject.

\section{Methodology}

This study is based on diffusion of innovative theory of Rogers (2005) who postulated that learning is impacted by the engagement of sensory apparatus of the learners for concretizing the learning processes. He emphasized adoption of innovative or new ideas and that this innovation is communicated through certain channels over time for the users to understand the need for the innovation and perceive better in economic and meaningful terms for possible adoption. The study adopted the quasi experimental design with pre-test, post-test non randomized control group design where SSII Commerce students were treated to blended instruction in their intact classes. Three research questions and three Null hypotheses were postulated to direct the study. There are 4,556 senior secondary II Commerce students in the 13 secondary schools in Uyo Local Government Area in Akwa Ibom State. The sample size of 240 students took part in the study i.e. 120 students from each of the urban and rural schools in their intact classes of 60 each. Criteria were set to select the schools and the subjects for the study namely; that schools with internet connectivity and schools that are co-educational. Four schools met the criteria and simple random sampling technique through balloting was used in selecting two schools, one in the urban and one in the rural setting.

In each school, SSII Commerce students were grouped into Experimental and control groups of 60 students. The experimental package was developed with the help of the Material-First-Rationale-Model of Taylor, (1980) and Briggs (1974) who based instructional processes on a more flexible systematic approach. They assumed that curriculum and objectives tend to come from the instructional strategy and materials as channels of classroom communication. The package was developed on trade, transport and production as a unit of instruction using Power point and interactive white board (smart board) to mediate the instruction. All the 240 students were pre-tested with the Performance Test. The control groups were taught using the expository instructional strategy while the experimental groups were treated with the package with the help of their class teachers that were trained on the purpose.

An instrument tagged Commerce Performance Test (CPT) was de veloped with 25 ite ms for Pre and Post-test. The items were developed on multiple choice options of (A-D) with only one correct option. Students were to choose which option carried the correct answer. The instrument was face and content validated by three experts from the Department of Educational Technology; department of Business Administration and Department of Educational Foundations (Measurement and Evaluation unit) all in University of Uyo-Nigeria. They moderated the items that help in the collection of Data for analysis.

Test-retest reliability strategy was adopted. The data were coded and treated to Kuder-Richardson formula 21 . The analysis yielded a reliability co-efficient of .78. The instrument was therefore regarded as being reliable and should be used for the study. Data were analysed using mean and standard deviation in answering research questions while analysis of covariance (ANCOVA) was used in testing the postulated hypotheses. ANCOVA is used because of the involvement of two instructional strategies and four groups of test scores (pre-test and post-test scores) for both experimental and control groups.

\section{Data Anal ysis and Discussion of Findings}

\section{A: Answering of Research Questions:}

Three research questions were postulated for the study and the research questions are answered below:

\section{Research Question 1}

Is there any significant difference in academic Performance of SSII Commerce Students taught using Blended Instructional Strategy and those taught using expository strategy?

Mean and standard de viation was used for answering this research question and the result of the analysis is as presented in Table 1.

Table 1. Mean and standard deviation of the difference in Academic Performance of students taught Commerce using blended instructional strategy and those taught using expository strategy

\begin{tabular}{lllclcc}
\hline Instructional strategies & \multicolumn{2}{c}{ Pre-test } & PD & $\overline{\boldsymbol{X}}$ & Post-test & Mean-difference \\
& $\mathbf{n}$ & $\overline{\boldsymbol{X}}$ & SD & \\
\hline Blended instructional strategy & 120 & 16.08 & 8.45 & 68.98 & 11.93 & 52.90 \\
Expository strategy & 120 & 13.05 & 4.61 & 55.21 & 13.66 & 42.16 \\
\hline $\mathrm{n}=240$ & & & & & &
\end{tabular}


The analysis shows a mean difference of 52.90 for experimental group over that of expository group of 42.16 . This means that the use of blended instructional strategy in teaching commerce enhances students' performance than those taught with expository method.

Research Question 2: What difference exists in the academic Performance of male and female Students taught commerce using Blended Instructional Strategy and those taught using expository strategy?

Mean and standard deviation was used for answering this research question, the analysis is as seen in Table 2 .

Table 2. Mean and standard deviation of the difference in Academic Performance of male and female students taught Commerce using blended instructional strategy and those taught using expository strategy

\begin{tabular}{|c|c|c|c|c|c|c|c|}
\hline \multirow[t]{2}{*}{ Instructional strategy } & \multirow[t]{2}{*}{ Gender } & \multicolumn{3}{|c|}{ Pre-test } & \multicolumn{2}{|c|}{ Post-test } & \multirow[t]{2}{*}{ Mean-difference } \\
\hline & & $\mathbf{n}$ & $\bar{X}$ & SD & $\bar{X}$ & SD & \\
\hline \multirow[t]{2}{*}{ Blended } & Male & 31 & 41.50 & 9.02 & 71.33 & 13.83 & 29.83 \\
\hline & Female & 29 & 41.17 & 9.07 & 63.50 & 14.21 & 22.33 \\
\hline \multirow[t]{2}{*}{ Expository } & Male & 28 & 31.20 & 9.83 & 60.14 & 9.87 & 28.94 \\
\hline & Female & 32 & 30.84 & 4.80 & 55.11 & 6.47 & 24.27 \\
\hline
\end{tabular}

$\mathrm{n}=120$

The result of the analysis on Table 2 shows that male students performed better than their female counterparts when they were taught using blended instructional strategy in both the experimental and control groups. However, both male and female students performed better when taught with blended instructional strategy. Generally, male performed better than their female counterparts when they were taught with blended instructional strategy. The mean difference of 29.83 and 22.33 realized for use of blended instructional strategy were higher than that of expository group of 28.94 and 24.27 for male and female. This means that use of blended instructional strategy enhanced academic performance of male and female students but male students performed better than their female counterparts.

Research Question 3

What difference exists in the academic performance of urban and rural students taught commerce using blended instructional strategy and those taught using the traditional expository method?

Mean and standard de viation were used for answering this research question. The result of the analysis is as presente $\mathrm{d}$ in Table 3.

Table 3. Mean and standard de viation of the difference in the academic performance of urban and rural students taught commerce using blended instructional strategy and those taught using conventional method

\begin{tabular}{lllrrrrr}
\hline Instructional strategy & Location & Pre-test & \multicolumn{2}{l}{ Post-test } & \multicolumn{2}{c}{ Mean-difference } \\
& & $\mathbf{n}$ & $\overline{\boldsymbol{X}}$ & SD & $\overline{\boldsymbol{X}}$ & \multicolumn{1}{l}{ SD } & \\
\hline Blended & Urban & 34 & 35.17 & 8.86 & 62.33 & 7.96 & 27.16 \\
& Rural & 26 & 28.67 & 5.01 & 46.67 & 11.62 & 18.00 \\
Expository & Urban & 34 & 35.83 & 9.83 & 56.50 & 9.57 & 20.67 \\
& Rural & 26 & 33.43 & 8.80 & 50.10 & 10.18 & 16.67 \\
\hline
\end{tabular}

$\mathrm{N}=120$

An examination of Table 3 shows that urban based -students performed better than their rural counterparts when they were taught using blended instructional strategy. The mean difference of 27.16 was higher than 18.00 from the rural schools. For the expository group, the mean difference of 20.67 derived from the urban school was higher than 16.67 from the rural schools. This means that blended instructional strategy improves academic performance of students in the urban and rural schools and the impact is felt in urban than rural schools.

\section{B. Testing of Hypotheses}

\section{Hypothesis One}

There is no significant difference in the academic performance of students taught commerce using blended instructional strategy and those taught using traditional expository method

Analysis of co-variance was used in testing the hypothesis as presented in Table 4. 
Table 4. Result of ANCOVA analysis of the difference in the academic performance of students taught commerce using blended instructional strategy and those taught using expository method

\begin{tabular}{|c|c|c|c|c|c|c|}
\hline Source & $\begin{array}{l}\text { Type III Sum of } \\
\text { Squares }\end{array}$ & df & $\begin{array}{l}\text { Mean } \\
\text { Square }\end{array}$ & F -cal. & F-crit. & $\begin{array}{l}\text { Decision at } \\
P<.05\end{array}$ \\
\hline Corrected Model & $12605.237^{\mathrm{a}}$ & 2 & 6302.618 & 39.381 & & \\
\hline Intercept & 373138.214 & 1 & 373138.214 & 2.332E3 & & \\
\hline Pre-test & 1220.199 & 1 & 1220.199 & 7.624 & & \\
\hline $\begin{array}{l}\text { Instructional } \\
\text { strategies }\end{array}$ & $11991.473 *$ & 1 & 11991.473 & 74.93 & 3.07 & significant \\
\hline Error & 37929.559 & 237 & 160.040 & & & \\
\hline Total & 975949.000 & 240 & & & & \\
\hline Corrected Total & 50534.796 & 239 & & & & \\
\hline
\end{tabular}

An examination of Table 4 reveals that the calculated F-value of 74.93 is greater than the critical F-value of 3.07 at degrees of freedom 1 and 119 at .05 level of significant. Therefore, the Null hypothesis of no significant difference in the academic performance of commerce students taught with blended instructional strategy and those taught with expository method is rejected. This implies that there is a significant difference in the performance of commerce students taught with blended instructional strategy and those taught with expository method.

Hypothesis 2: There is no significance difference in the academic performance of male and female students taught commerce using blended instructional strategy.

The hypothesis was tested using Analysis of Covariance as seen on Table 5.

Table 5. Result of ANCOVA of the difference in the academic performance of male and female students taught commerce using blended instructional strategy

\begin{tabular}{|c|c|c|c|c|c|c|}
\hline Source & $\begin{array}{l}\text { Type III Sum of } \\
\text { Squares }\end{array}$ & df & $\begin{array}{l}\text { Mean } \\
\text { Square }\end{array}$ & F -cal. & F-crit. & $\begin{array}{l}\text { Decision at } \\
P<.05\end{array}$ \\
\hline Corrected Model & $8833.110^{\mathrm{a}}$ & 3 & 2944.370 & 16.813 & & \\
\hline Intercept & 49807.175 & 1 & 49807.175 & 284.411 & & \\
\hline Pre-test & 334.976 & 1 & 334.384 & 4.448 & & \\
\hline Main Effect* & 2113.076 & 2 & 1056.538 & $6.03 *$ & 3.07 & significant \\
\hline Error & 20314.357 & 116 & 175.124 & & & \\
\hline Total & 552924.000 & 120 & & & & \\
\hline Corrected Total & 29147.467 & 119 & & & & \\
\hline
\end{tabular}

The result of analysis as shown in Table 5 indicates that there is a significant difference in male and female students' academic performance in commerce when blended instructional strategy was used for instruction. The calculated $\mathrm{F}$-value of 6.03 is higher than the critical F-value of 3.07 at 1 and 119 degrees of freedom at .05 level of significance. With this result, the null hypothesis of no significant difference in male and female students' academic performance taught with blended instructional strategy is rejected. This implies that a significant difference exists in male and female students' academic performance in commerce when blended strategy was used for instruction.

Hypothesis Three: There is no significance difference in the academic performance of urban and rural students taught commerce using blended instructional strategy.

The hypothesis was tested using Analysis of covariance as presented in Table 6.

Table 6. Result of ANCOVA of the difference in the academic performance of urban and rural students taught commerce using blended instructional strategy and those taught using expository method

\begin{tabular}{|c|c|c|c|c|c|c|}
\hline Source & $\begin{array}{l}\text { Type III Sum of } \\
\text { Squares }\end{array}$ & df & $\begin{array}{l}\text { Mean } \\
\text { Square }\end{array}$ & F -cal. & F-crit. & $\begin{array}{l}\text { Decision at } \\
P<.05\end{array}$ \\
\hline Corrected Model & $7353.305^{\mathrm{a}}$ & 2 & 3676.653 & 40.455 & & \\
\hline Intercept & 10380.712 & 1 & 10380.712 & 114.220 & & \\
\hline Pre-test & 3075.804 & 1 & 3075.804 & 33.843 & & \\
\hline Main Effect* & 5362.276 & 1 & 5362.276 & $59.00 *$ & 3.07 & significant \\
\hline Error & 10633.362 & 117 & 90.883 & & & \\
\hline Total & 419350.000 & 120 & & & & \\
\hline Corrected Total & 17986.667 & 119 & & & & \\
\hline
\end{tabular}

$\mathrm{N}=120$

The result of the analysis as presented on Table 6 indicates that there is a significant difference in students' academic performance in urban and rural schools taught Commerce with blended instructional strategy. The calculated $\mathrm{F}$-value of 
59.00 is higher than the critical F-value of 3.07 at 1 and 119 degrees of freedom and at .05 level of significance. With this result, the null hypothesis of no significant difference in students' academic performance in urban and rural schools taught commerce with blended strategy is rejected.

\section{Discussion of Findings}

The result of the analysis revealed a is significant difference in the academic performance of students taught commerce using blended instructional strategy and those taught using expository method. This result could be attributed to the fact that students could have been motivated to learn when such an innovative instructional strategy like the blended instructional strategy is used which in turn could lead to them paying great attention to the lesson and consequently mastering what is being taught, this in turn could be manifested through improved academic performance. This finding agrees with the assertion of Rose and Gage (2006) that online students tend to be less satisfied with totally online courses when compared to traditional courses. Therefore, a combination of online and traditional learning environment could be much more productive in terms of teaching and students' performance. The findings also agrees with the assertion of Graham (2006), that blended learning was developed for its potential advantages in offering a more effective education, convenience and access to teaching learning environment.

The result of the analysis showed a significant difference in the academic performance of male and female students taught commerce using blended instructional strategy. The reason for this result is that male students are more articulated in the use of technologies than their female counterparts. Females are however better in language than science and social sciences. This finding could also be due to the fact that male students can withstand harder task than female students. This finding is in support of the study of Mbaba (2010), Okoeye (2009) and Chang (2007) as well as Angrist (2009) who found out a significant difference in the academic performance of both male and female students in various subject areas. It is also supported by the submission of Mkpughe (2008) who discovered that males learn better than their female counterparts in many subject areas.

The result of the analysis also revealed that there is a significant difference in academic performance of students in urban and rural schools taught commerce using blended instructional strategy. This result implies that location has significant influence on the use of blended instructional strategy and the academic performance of students in commerce. The reason for this result is that students in the urban areas are more exposed to ICT resources and network services than in the rural areas. This finding is supported by the work of Okeye (2009), Owoeye and Yara (2007) who submitted that environment is a major determinant of scholastic performance among learners and that academic performance of students differ between urban and rural areas.

\section{Conclusion}

Based on the findings of the study, it was concluded that blended instructional strategies as innovative instructional strategy could enhance students' performance irrespective of location, generate a lot of motivation, reinforcement and secure attention. This can help to generate interest and cause students to take active part in their own learning thereby enhancing and facilitating their academic performance.

\section{Recommendations}

The following recommendations were made to diversify teacher's instructional strategies:

1. Teachers should strive to use blended instruction as innovative instructional strategies in teaching commerce as this will help to concretize learning and hence facilitate academic performance of students.

2. ICT facilities should be installed in both urban and rural areas to enhance the adoption of blended instructional strategy and other innovative ICT driven strategies.

3. Teachers should be equipped with computers and other ICT facilities to enable them use as at when due.

4. In-service training, seminars, workshops and conferences should be organized by the Ministry of Education, Government and NGOs to train teachers on the use of innovative pedagogical strategies including blended instruction.

\section{References}

Angrist, S. C. (2009). Three Models of group learning strategies, Mathematics ability and gender as determinants of secondary schools learning outcome in Map work. Unpublished Ph. D. Thesis, University of Ibadan, Ibadan.

Briggs, L. G. (1974). A handbook of Procedures for the design of Instruction. Pittsburgh: P. A. American Institute of Research.

Etim, P. J. (2016). Principles of Instructional Design and Communication. Uyo: Mef, Nig. Ltd. 
Grahann, C. R. (2006). Blended learning system: definition, current trends and future directions. The handbook of blended learning global perspectives.

Guetzeekeep, C. J. (2008). Pupils Preference for Science subjects. British Journal of Educational Psychology, 7(8) 101-105.

Kim, S., \& Chang, M. (2007). The Differential Effects of Computer Use on Academic Performance of Students from Immigrant and Gender Groups. Implications on Multimedia enabled Education. ISMW'07. In proceedings of the $9^{\text {th }}$ IEEE International Symposium on Multimedia Workshops. IEEE Computer Society Washington, D. C: USA.

Mbaba, U. G. (2010). Teaching Strategies, Student's Characteristics and Academic Performance in Mathematics and Technology in Akwa Ibom State. Unpublished Thesis submitted to the University of Uyo, Uyo-Nigeria.

Mkpughe, Z. (2008). Video disc and its impact in the classroom, Journal of Computers and Education, 42,111-131.

Murphy, P. (2003). The hybrid strategy: Blended face-to-face with virtual instruction to improve large lecture courses.

Okoye, N. S. (2009). The Effect of gender, Socio-economic status and school location on students' Performance in Integrated science. Result from Research department of Science Education. Delta State University Abraka, Nigeria Mimeograph.

Okworo, G. S. (2008). Effect of Teaching Strategies in Secondary School Students Achievement and Retention in Christian Religious Knowledge using Instructional Television. An Unpublished Ph. D Thesis submitted to the University of Uyo, Uyo-Nigeria.

Owoeye, J. S., \& Yara, P. O. (2007). School Location and Academic Achievement of Secondary Schools in Ekiti State, Nigeria. Retrieved from www.(csenet.org/Journal/Index/Php/ass/article/view/10358 on $4^{\text {th }}$ May, 2016.

Picciano, A. G. (2006). Online learning: implications for higher education, pedagogy and policy. Journal of thought, 41(1), 75-120.

Rogers, E. M. (2005). Diffusion of Innovation ( $5^{\text {th }}$ ed.) New York Free Press

Rose, B., \& Gage, K. (2006). Global perspective on blended learning insight from webCT and our customers in Higher Education. The handbook of Blended Learning.

Salamh, A. (2005). The effectiveness of using the internet on the achievement of Jerusalem Open Uni versity students in the use of Computer in Education Course. Journal Education Bahrain, 3(1), 220-234.

Scida, E. E., \& Saury, R. E. (2006). Hybrid courses and their impact on students and classroom performance: a case study at the University of Virgina. Calico Journal, 23(3), 517-531.

Taylor, W. D. (1980). Teacher and Materials. The Selection process in secondary school video in M.A Cambre (ed.). Agency for Instructional Television. Bloomington: Indiana.

Throne, K. (2003). Blended learning: How to integrate online and traditional learning. Kogan Page Limited, Britain.

Young, J. R. (2002). Hybrid teaching seeks to end the divide between traditional and online instruction. The Chronicle High Education, 48(28), 33-34.

\section{Copyrights}

Copyright for this article is retained by the author(s), with first publication rights granted to the journal.

This is an open-access article distributed under the terms and conditions of the Creative Commons Attribution license which permits unrestricted use, distribution, and reproduction in any medium, provided the original work is properly cited. 